\title{
Retraction Note: Surface modification of aramid fibers with novel chemical approach
}

Tie-Min Liu $\cdot$ Yuan-Suo Zheng $\cdot$ Jie Hu

Published online: 8 June 2012

(C) Springer-Verlag 2012

Retraction Note: Polym. Bull. (2011) 66:259-275

DOI 10.1007/s00289-010-0313-y

This article has been retracted at the request of the editor because substantial parts were previously published in Journal of Applied Polymer Science 118, 2541 (2010).

The online version of the original article can be found under doi:10.1007/s00289-010-0313-y.

T.-M. Liu ( $ه)$

School of Material Science and Engineering, Xi'an Jiao Tong University, Xi'an,

Shaanxi 710049, People's Republic of China

e-mail: liliang5054@163.com

Y.-S. Zheng · J. Hu

School of Science, Xi' an Jiao Tong University, Xi'an, Shaanxi 710049, People's Republic of China 